\title{
ANALYSIS OF COST CONTROL, TIME, AND QUALITY ON CONSTRUCTION PROJECT
}

\author{
Dewi Nusraningrum \\ Faculty of Economics \& Business, Universitas mercu Buana \\ dewinusraningrum@mercubuana.ac.id \\ Joko Priyono \\ Faculty of Economics \& Business, Universitas mercu Buana \\ jokopriyono47@gmail.com
}

\begin{abstract}
This research aims to analyze the relationship of delay time and costs with estimated that causes increased costs from perspective of management fees project with earned value method and to analyze the influence of the variables associated with the quality control at each stage of the work concreting. Secondary data collection i.e. the draft budget, the curve S, financing and weekly reports the progress of the project. Primary data i.e. questionnaires to 30 respondents. The cost control and time used earned value methods, and quality control with multiple linear regression. The results of the research project performance until the 27th week of aspects of cost and time projects implementation are not experiencing excess costs, but suffered delays. Regression analysis a very influential determinant variables of each job of making concrete to install formwork: concrete level marking and dimensions for formwork, ironing: the connection reinforcement iron and iron a clean free from rust, oil, and dry concrete, for concreting: checking of slump test and the amount of labor, and to uninstall the formwork: concrete age and concrete level according to plan.
\end{abstract}

Keywords: cost control; time control; earned value; quality.

\begin{abstract}
Abstrak
Penelitian ini bertujuan mengetahui hubungan keterlambatan waktu dan biaya dengan estimasi yang menyebabkan peningkatan biaya dilihat dari manajemen biaya proyek dengan metode earned value dan mengetahui pengaruh variabel-variabel yang terkait dengan pengendalian mutu pada setiap tahap pekerjaan pembetonan. Pengumpulan data sekunder yaitu RAB, kurva $S$, laporan mingguan pembiayaan dan kemajuan proyek. Data primer yaitu kuesioner kepada 30 responden. Metode yang digunakan pengendalian biaya dan waktu dengan earned value dan pengendalian mutu dengan regresi linier berganda. Hasil penelitian kinerja proyek sampai minggu ke-27 dari aspek biaya dan waktu pelaksanaan proyek tidak mengalami kelebihan biaya, tetapi mengalami keterlambatan. Analisis regresi variabel penentu yang sangat berpengaruh dari masing-masing pekerjaan pembetonan yakni untuk pasang bekisting: marking level cor dan dimensi bekisting, untuk pembesian: sambungan besi tulangan dan besi bersih bebas dari karat, oli, dan beton kering, untuk pengecoran: pengecekan slump test dan jumlah tenaga kerja, dan untuk bongkar bekisting: umur beton dan level cor sesuai rencana.
\end{abstract}

Kata Kunci: pengendalian biaya; pengendalian waktu; earned value; mutu JEL: C3 


\section{Research Background}

Implementation of the construction project are frequent discrepancies between the schedule plan and realization in the field that can lead to an implementation time, swelling costs decline, and it is the quality of the resulting building. The cause of these problems is the design changes, weather factors, less the needs of the labour, material or equipment, and others. Project control systems required to maintain alignment between planning and execution. Planning is made in principle as a basis of reference for the implementation. The reference material is subsequently became the standard implementation project that includes a schedule, budget, and technical specifications. During the process of controlling, monitoring should be performed during the execution of the project so that it can be known the achievements and progress of the projects that have been achieved. The results of this monitoring information is useful for evaluation of the results that have been achieved at the time of reporting (Dimyati and Nurjaman 2016).

The delay in completion of the project could be detrimental to the company's contractors in the project construction of Intermodal Terminal in BSD City Area. Intermodal Terminal project with a value of $\mathrm{Rp} 86,460,650,000$ project cost, with the implementation of the start of the October 31, 2016, and was completed on November 30, 2017. To know the performance of the control project in the study viewed from project report, one of which is the progress weekly. In the review of development projects based on the weekly progress report from week 1 to week 27 (01 May-07 May 2017) and the value of the plan's cumulative 52.20\% and the value realization of cumulative $47.27 \%$ with a deviation- $4.93 \%$. That value that is greater than the cumulative plan realization of cumulative, so that the project experienced a delay in completion of the project. This can result in an increase in cost, implementation time and will affect the quality of the work of the resulting buildings.

Projects with budgets large enough but with a relatively short time made a project with a high degree of risk. Therefore, the control of costs, time, and quality is part of the overall project management. Cost control and time is done to minimize the errors project implementation efforts, prevent factors that slow down the achievement of the objectives in the project, and take the decisions or actions are needed to control the problem encountered, as well as being able to demonstrate the results of performance and productivity activities using earned value. As for the quality control is carried out the control at each stage of the work in order to minimize the failure of the quality of the work and ensure that the work has been carried out in accordance with the technical specifications. Quality has a correlation with the customer satisfaction and how company understand customer expectations (Maulana et al. 2019)

The time control is controlling the time of project implementation to match schedule (Pinontoan et al. 2015). The project schedule is a tool that can show when during any activities, so that it can be used to control the execution of the project as a whole. Scheduling provides information about project progress in terms of performance resources in the form of fees, labor, equipment and material as well as the duration of the project plan and the progress of time for the completion of projects (Aulady and Orleans 2016). Scheduling is allocated time available to carry out each job in order to complete a project until the optimal result is achieved by considering the limitations that exist. During the process of project control, scheduling follow the development of the project with a variety of problems. The process of monitoring and updating are always done to get the most realistic scheduling so that the allocation of resources and the determination of its duration in accordance with the goals and objectives of the project (Simanjuntak and Firmansyah 2014). Scheduling is made to describe the planning in the time scale. Scheduling determines when the activity is started, delayed, and resolved, so that the financing and the use of resources will be adjusted according to the needs of time to be determined (Daulasi et al. 2016:76). Schedule control includes the process necessary to ensure timely project completion. Set up a development project with the appropriate time, in 
accordance with the approved fee as well as a good performance is very hard to do (Dimyati and Nurjaman 2016).

Curve $\mathrm{S}$ is a picture of the relationship between the implementation time of the project with the value of the accumulation process of the implementation of the project started from the beginning until the project is completed. Generally the project using the curve $S$ in the planning and control of the project implementation schedule. Progress curve graphically can provide various size of progress on an upright axis is associated with the units of time horizontally. The cumulative percentage made forming the curve of cumulative percentage of $\mathrm{S}$, the realization is a tangible results in field. The results of the realization of the work at any one time can be compared to the plan, if the results of the realization is above the curve $S$, then it happens achievement but if it is under the curve $S$ need to evaluate thoroughly or need for rescheduling (Efendi and Sumarsiddin 2015).

The cost of the project or budget plan costs a building or project is the calculation of the number of cost necessary for materials and wages, as well as other costs related to the execution of building or project. Budget cost is the price of building materials are counted carefully, meticulously, and qualified. Cost budget in the same building will vary in each region, due to the difference in price of materials and labor wages. Project cost control needed so that projects can be carried out in accordance with the planned initial cost (Daulasi et al. 2016). Cost control is the control of project cost in order not to exceed the budget. The preparation of the budget the cost of the project is meant to monitor and analyze whether the total cost of the plan in accordance with the costs of their implementation. In this way can we know when the project implementation in this case the contractor makes a profit or loss (Pinontoan et al. 2015). Cost control include processes that are necessary to ensure that the project is completed with the funds that have been agreed upon. Cost control is not only a monitoring costs and recording the amount of data, but also data analysis so that the Act of correction can be done before it's too late. Cost control is performed by all personnel, both in the organizational structure of project management the project owner and the main contractor. Notwithstanding the foregoing, the owner of project management should be responsible for the cost control of the project, including the management of funding, approval, and payment of bills from the main contractor as well as the control of funds/budget (Dimyati and Nurjaman 2016). Cost control of projects is distinguished into two types, namely the Direct Cost and Indirect Cost. Step control techniques are set a target or standard time for a work to be completed with certain controls. If a part of the complete work targeted have been implemented, as compared with the actual achievement of the target. After that, give appraisal, do evaluations and set the influence of accomplishment now against future earnings prospects. If necessary, plan reworked the original so the target could be achieved or can be approached (Efendi and Sumarsiddin 2015:35). Cost control is the final step of the process management of project costs i.e. cost of expenditure in order to initiate the appropriate project planning, in the form of a predetermined budget. Thus, aspects and cost control object will be identical to the planning costs, so that various types of activities at Headquarters and the field should always be monitored and controlled so that its implementation in accordance with the predetermined budget (Rantung et al. 2014).

Budget cost is the price of a building calculated with the detailed, meticulous, and qualified. Cost budget in the same building will vary in every area because of the difference in price of building materials and labor wages (Dimyati and Nurjaman 2016). Thus, cost control is the process of monitoring of project costs through budget plan costs (RAB) as measured through the calculation of volume, unit price analysis, and determination of fees. Quality control, a part of quality management focused on the fulfillment of requirements such as monitoring, reduce problems, and irregularities identified (one by Rivelino, 2016:5). Quality Control is monitoring specific project results to determine whether they comply with relevant quality standards and identify ways to eliminate causes of unsatisfactory performance 
(Ashokkumar 2014). Quality control and engineering activity is an activity monitor, evaluate and follow up the order for the requirements that have been set are achieved (Santosa, 2013), (Dimyati and Nurjaman 2016). Quality control is a technique and a planned actions/activities that done to achieve, maintain, and improve the quality of a product and services to fit the predetermined standards and can satisfy the consumer satisfaction (Rustendi 2012). Meet the quality is the target management project, with construction products quality meet the requirements that are generated will meet the quality standard expected to function satisfactorily in a certain time or ready-made (Hadiono 2010).

Technical specification contains a description of the rules to be used, the scope of the work, material requirements, terms of execution of the work, equipment requirements, and other special requirements of the job-the job specified. Technical specification has a higher hierarchy levels compared to the picture because when seen from a chronological authors, technical specifications were made to explain, affirm, and specified things that have not been listed in the images (Dimyati and Nurjaman 2016). Technical specifications are measured through the scope of the work, material requirements, terms of execution of the work, equipment requirements, and other special requirements of the jobs. Reporting is an activity that has been carried out which includes the type of work performed, the quantity or volume of work, as well as things that are non-technical, such as the State of the weather at the time of execution of the work. (Dimyati and Nurjaman 2016).

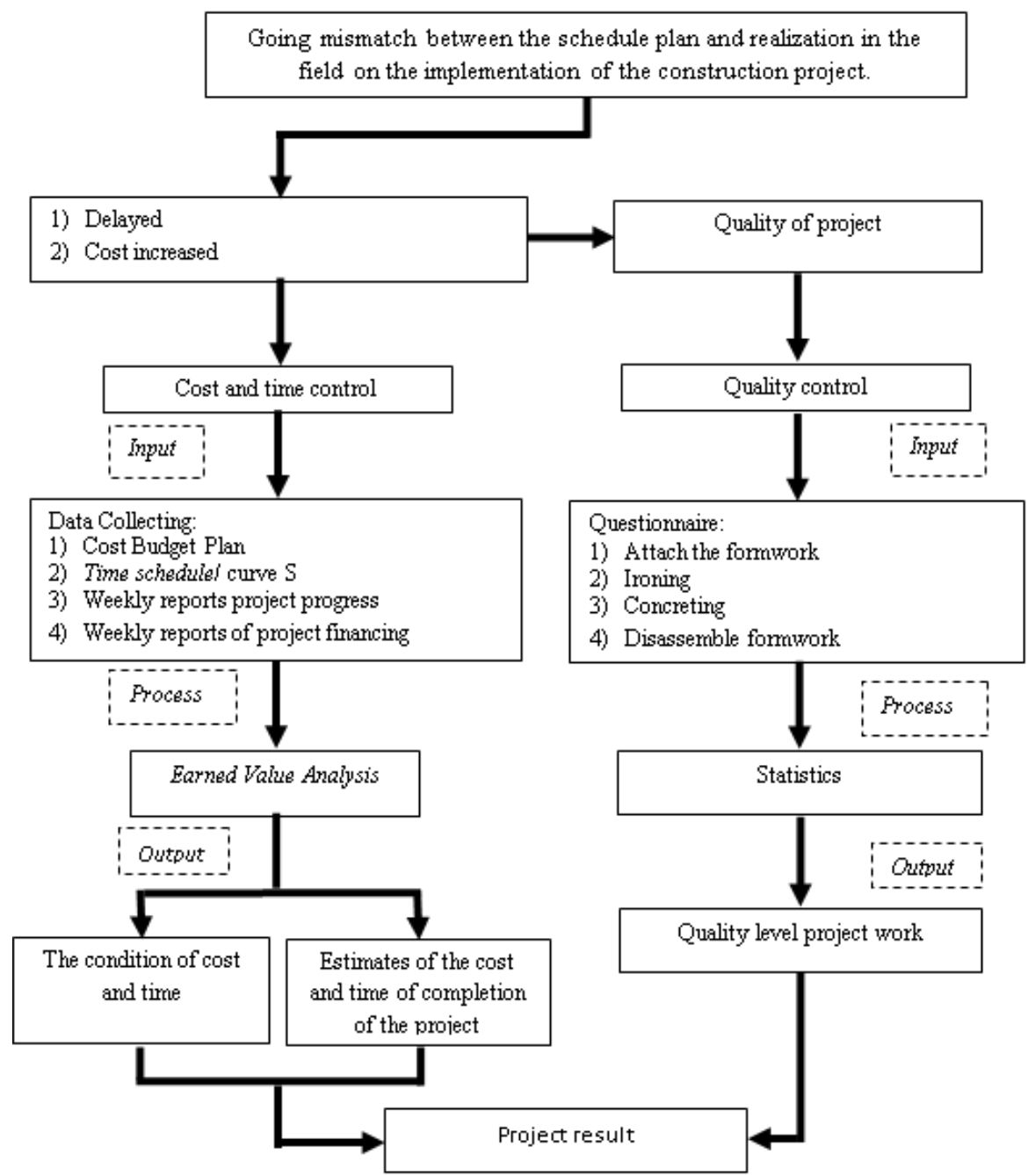

Figure 1. The framework of thought 


\section{Research Method}

The population of cost control and time is three (3) project area Intermodal BSD City, namely Intermodal Terminal, Modern market 2, and Intermodal station of BSD City. Sample cost control and time using a purposive sampling (engineering data retrieval with specific consideration) i.e. Intermodal Terminal of BSD City. Population quality control are the parties directly involved in the implementation of the project (project owners, contractors, and consultants). Quality control samples using probability sampling by means of simple random sampling, namely members of the population sampling was done randomly without regard to strata (level) in the population of members, namely with the sample 30 the respondent. Quality control questionnaire developed from the technical specifications and SOP (standard Operational Procedure).

Data for analyzing cost control and time; budget plan, Time schedule/curve S, weekly reports the progress of the project, financing the project weekly reports.

Analysis of cost control and time use earned value method by calculating; a) ACWP (Actual Cost of Work Performed), b) BCWP (Budgeted Cost of Work Performed), c) BCWS (Budgeted Cost of Work Schedule), d) BAC (Budget At Completion). Quality control analysis using regression analysis.

\section{Result and Discussion}

The concept of earned value analysis in project implementation performance data using the Budged Cost of work Schedule (BCWS), Budged Cost Of Work Performed (BCWP), Actuale Cost Of Work Performed (ACWP).

The third indicator analyzed until the 27th week with the following values: first is $\mathrm{Rp}$ 45.129.865.481, second is Rp 41.104.257.617, and the third is Rp 35.546.498.296.

Indicators BCWS, BCWP, ACWP gives an overview about the accomplishments of the schedule and budget.

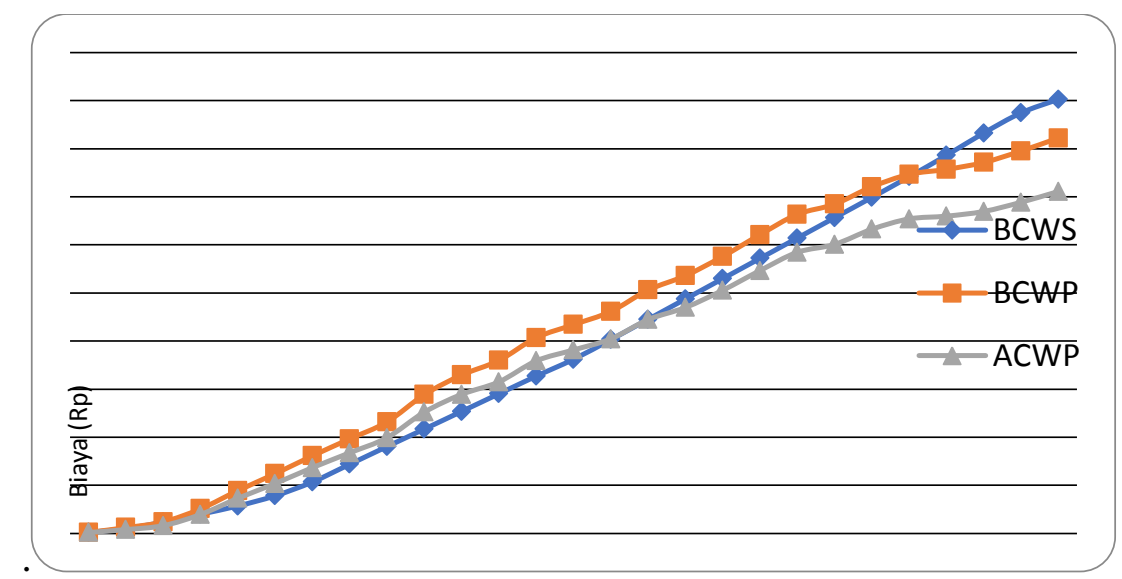

Figure 2. Curve S Earned Value

Curve $\mathrm{S}$ earned value on the $1^{\text {st }}$ week until the $23^{\text {rd }}$ week BCWP $>$ BCWS shows under run schedule and ACWP $<$ BCWP under run cost. On the $24^{\text {th }}$ week until $27^{\text {th }}$ week value $\mathrm{BCWP}<\mathrm{BCWS}$ over run schedule and ACWP < BCWP under run cost. Cost Variance $(\mathrm{CV})$ is the difference between the values obtained after completion of the pekerjaaan with the actual costs that occur during the execution of the project. On the negative value $\mathrm{CV}$ number value which indicates that the fees are higher than budget (over run cost), the value of zero indicates the work done on cost, and a positive value means work gets done and costs less than budget (under run cost). Analysis Cost variance $(\mathrm{CV}) 27^{\text {th }}$ week: 


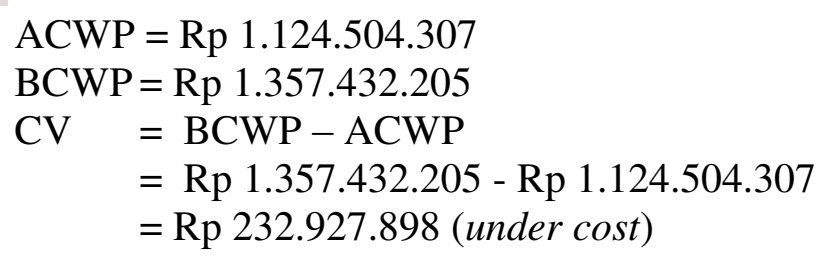

Schedule Variance (SV) is the calculation of the deviation between the BCWP with BCWS. On the numerical values for the SV value is positive indicates that the project work the concluded more than a plan, the value of zero indicates the work done right on schedule, and a negative value indicates a bad job performance because of work the completed fewer than the planned schedule. Analysis Schedule Variance (SV) $27^{\text {th }}$ week:
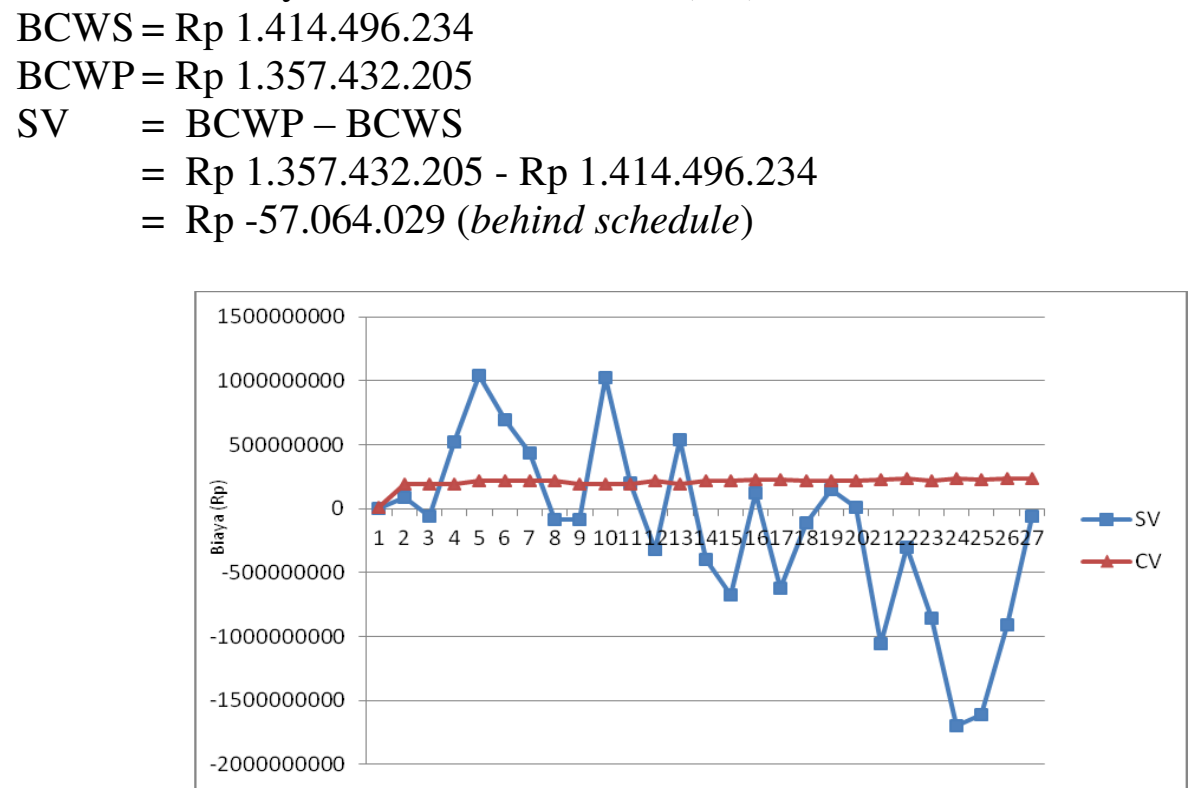

Figure 3. Graph identification of variant of SV and CV

In Figure 3 graph identification of variant of SV and CV the week 27th retrieved results $\mathrm{SV}=-57.064 .029$ and the value of $\mathrm{CV}=+232.927 .898$. This means that the progress of the work carried out for longer than that in the schedule of the plan. While the cost cost less than the cost of previous plans.

Cost Performed Index (CPI) a factor cost efficiencies that have already been issued can be demonstrated by comparing the value of the work, has been completed (BCWP) with actual costs that have been incurred in the same period (ACWP). Analysis Cost Performed Index (CPI) $27^{\text {th }}$ week.

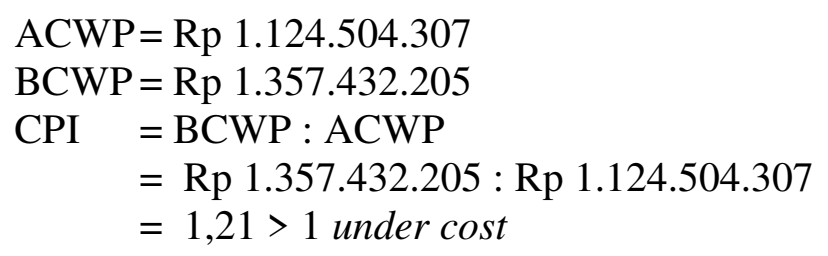

Schedule Performed Index (SPI) efficiency factor is the time the work has been executed can be demonstrated by comparing the time the work has been completed (BCWP) with the planned time (BCWS) in the same period. The value of the SPI shows how big the job is able to be settled against a unit of work that is planned. Schedule Performed Index (SPI) $27^{\text {th }}$ week:
BCWS $=$ Rp 1.414.496.234
$\mathrm{BCWP}=\mathrm{Rp} 1.357 .432 .205$
SPI = BCWP : BCWS 


$$
\begin{aligned}
& =\operatorname{Rp} 1.357 .432 .205: \operatorname{Rp~1.414.496.234~} \\
& =0,98<1 \text { (behind schedule) }
\end{aligned}
$$

$$
\begin{array}{ll}
\text { Critical Ratio }(\mathrm{CR}) 27^{\text {th }} \text { week. } \\
\text { SPI } & =0,98 \\
\text { CPI } & =1,21 \\
\text { CR } & =\text { SPI } \times \text { CPI } \\
& =0,98 \times 1,21 \\
& =1.16>1 \text { critical comparison of the Organization of the project faster }
\end{array}
$$

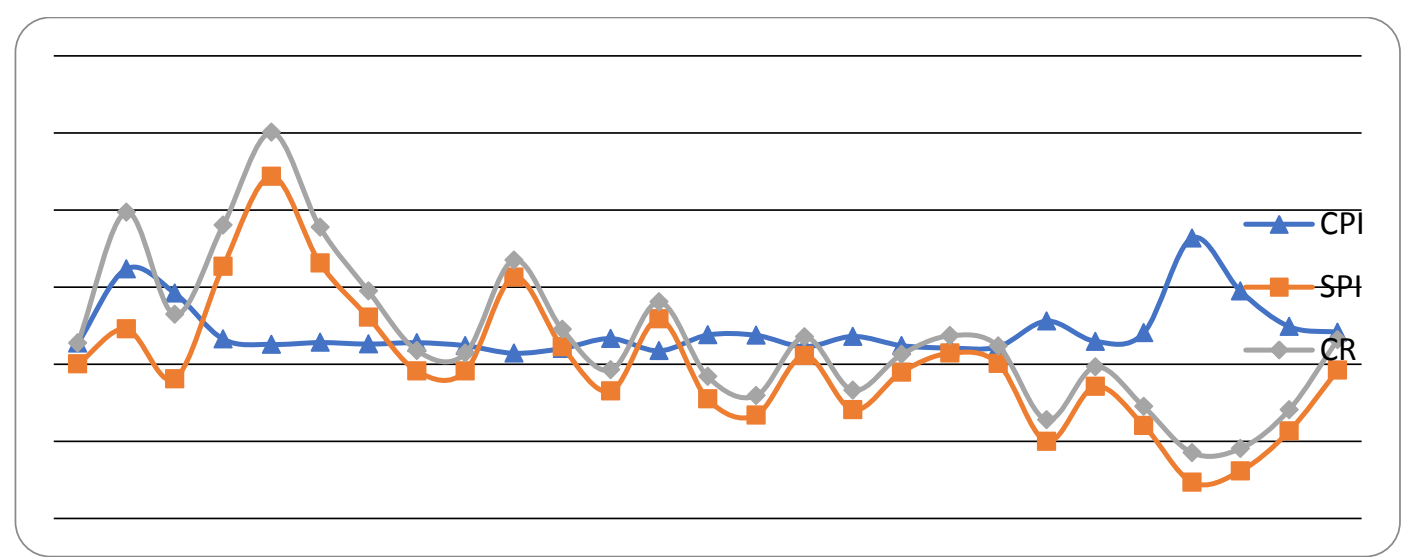

Figure 4. Graph Identification value of the CPI, SPI, and CR

This figure SPI $<1$ shows the performance of the projects experienced delays of the schedule. Whereas a value CPI $>1$ indicating expenditure costs are lower than the budget for the work that has been carried out. In terms of CR $>1$ critical comparison of the Organization of the project faster.

Estimate Temporary Schedule (ETS) $27^{\text {th }}$ week.

The rest of the time

SPI

ETS

$$
\begin{aligned}
& =55-27=28 \text { week } \\
& =1 \\
& =(\text { the rest of the time }) / \mathrm{SPI}+\text { total time } \\
& =28 / 1=28 \text { week }
\end{aligned}
$$

Estimate All Schedule (EAS) $27^{\text {th }}$ week.

The time of completion of the project $=55$ week

ETS

$$
\begin{aligned}
& =28 \text { week } \\
& =\text { end time }+ \text { ETS } \\
& =55+28=83 \text { week }
\end{aligned}
$$

From the results of calculation of the foreconcrete total project time known estimated time of completion of the project for 83 weeks.

$\Delta \mathrm{D}$

$$
\begin{aligned}
& =\mathrm{EAS}-\text { end time } \\
& =83-55=28(\text { additional time } \pm 28 \text { week })
\end{aligned}
$$

If a performance like this one will experience a delay from the initial schedule planning. Estimate to Complete (ETC) $27^{\text {th }}$ week.

$$
\begin{aligned}
& \text { BAC } \\
& =\operatorname{Rp} 86.460 .650 .000 \\
& \text { BCWP } \\
& \text { CPI } \\
& =\mathrm{Rp} 41.104 .257 .617 \\
& \text { ETC } \\
& =1,22 \\
& =(\mathrm{BAC}-\mathrm{BCWP}) / \mathrm{CPI} \\
& =(\operatorname{Rp} 86.460 .650 .000-41.104 .257 .617) / 1,22 \\
& =\operatorname{Rp} 37.177 .370 .806
\end{aligned}
$$

The value for job cost foreconcretes ETC remaining until the $27^{\text {th }}$ week of Rp 37.177.370.806. 
Estimate at Complete (EAC) is the magnitude of the costs will be absorbed by the overall project based on the data of the last achieved productivity. The analysis of the Estimate at Complete (EAC) $27^{\text {th }}$ week.

$$
\begin{array}{ll}
\text { ACWP } & =\operatorname{Rp} 35.546 .498 .296 \\
\text { ETC } & =\operatorname{Rp~37.177.370.806~} \\
\text { EAC } & =\text { ACWP }+ \text { ETC } \\
& =\operatorname{Rp~35.546.498.296+~Rp~37.177.370.806~} \\
& =\operatorname{Rp~} 72.723 .869 .102
\end{array}
$$

From the results of the calculation of the overall cost of the magnitude for concrete obtained projects amounting to $\mathrm{Rp} 72,723,869,102$. The value of the cost has decreased from budgeted costs for the work done.

Variance at Completion (VAC) that are expected to occur at the time the project has been completed on the basis of productivity last if performance pelaksanan project remain the same until the project is completed. Analysis of Variance at Completion (VAC) $27^{\text {th }}$ week.

$$
\begin{aligned}
& \text { BAC }=\mathrm{Rp} \mathrm{86.460.650.000} \\
& \text { EAC } \quad=\text { Rp 72.723.869.102 } \\
& \text { VAC } \quad=\text { BAC }- \text { EAC } \\
& =\mathrm{Rp} \text { 86.460.650.000 - Rp 72.723.869.102 } \\
& =\operatorname{Rp} 13.736 .780 .898
\end{aligned}
$$

The results of the rest of the budget of the project Rp 13.340.666.700 (15,89\%)

Multiple Regression Analysis of Install the Formwork.

Y_BK $=4,052+1,757$ BKBP8 $+0,476$ BKK3

Note:

Y_BK = jobs formwork

BKBP8 = marking level concrete in formwork

BKK3 = dimensi dalam bekisting

The equation is stated as follows. First, constants of 4.052 stated that if no variables BKBP8 and BKK3, then the quality level of formwork was 4.052. Second, the regression coefficient BKBP8 of 1.757 stated that any increase (because the mark (+)) 1 unit of BKBP8 will increase the quality level of formwork of 1.757. Third, the regression coefficient BKK3 of 0.476 stated that any increase (due to the (+) sign) 1 unit of BKK3 will increase the quality level of formwork of 0.476 .

Multiple Regression Analysis of Ironing.

Note:

$$
\text { Y_BS }=-0,499+(-0,214) \text { BSBP3 }+(-0,300) \text { BSK7 }
$$

$$
\begin{array}{ll}
\text { Y_BS } & =\text { ironing } \\
\text { BSBP3 } & =\text { Connection/overlay/cuttings iron reinforcement } \\
\text { BSK7 } & =\text { Iron is clean, free from rust, oil, and dry concrete }
\end{array}
$$

The equation is stated as follows. First, constants of-0.499 stated that if no variables BSBP3 and BSK7, then ironing quality evel-0.499. Second, the regression coefficient of 0.214-BSBP3 States that every decline (sign (-)) 1 unit of BSBP3 will lower the quality level of ironing0.214. Third, the regression coefficient of BSK7-0.300 stated that any decrease (because the sign (-)) 1 unit of BSK7 will lower the quality level of ironing-0.300. 
Multiple Regression Analysis of Concreting.

Note:

$$
\text { Y_CR }=8,387+0,337 \text { CRBP7 }+1,871 \text { CRK2 }
$$

$$
\begin{array}{ll}
\text { Y_CR } & =\text { concreting } \\
\text { CRBP7 } & =\text { slump test check } \\
\text { CRK2 } & =\text { the number of labor }
\end{array}
$$

The equation is stated as follows. First, constants of 8.387 stated that if no variables CRBP7 and CRK2, then the quality level concreting 8.387. Second, the regression coefficient CRBP7 of 0.337 stated that any increase (due to the (+) sign) 1 unit of CRBP7 will increase the level of quality of concreting 0.337 . Third, the regression coefficient CRK2 of 1.871 stated that any increase (due to the (+) sign) 1 unit of CRK2 will increase the level of quality of concreting 1.871.

Multiple Regression Analysis of Uninstall the Formwork.

Note:

$$
\text { Y_BKK }=0,893+1,149 \text { BBKBP3 }+0,954 \text { BBKK4 }
$$

Y_BBK = uninstall the formwork

$\mathrm{BBKBP}=$ concrete age

BBKK4 = concrete level according to plan

The equation is stated as follows. First, constants of 0.893 stated that if no variables BBKBP3 and BBKK4, then the quality level the work of uninstall the formwork is 0.893 . Second, the regression coefficient BBKBP3 of 1.149 stated that any increase (due to the (+) sign) 1 unit of

\begin{tabular}{|c|c|c|c|c|c|}
\hline No & Quality Control & F-test & t-test & R square & Durbin Watson Test \\
\hline 1 & $\begin{array}{c}\text { Install the formwork } \\
\text { - } \quad \text { BKBP8 } \\
\text { - } \\
\text { BKK3 }\end{array}$ & 28.671 & $\begin{array}{l}2.954 \text { (sig. 0.039) } \\
2.395 \text { (sig. } 0.024 \text { ) }\end{array}$ & 0.680 & 1.947 \\
\hline 2 & $\begin{array}{c}\text { Ironing } \\
\qquad \text { BSBP3 } \\
\bullet \text { BSK7 }\end{array}$ & 17,142 & $\begin{array}{l}2.508 \text { (sig. 0.014) } \\
2.275 \text { (sig. } 0.003 \text { ) }\end{array}$ & 0.559 & 1,728 \\
\hline 3 & $\begin{array}{l}\text { Concreting } \\
\qquad \quad \text { CRBP7 } \\
\text { • }\end{array}$ & 5.181 & $\begin{array}{l}2.332 \text { (sig. } 0.043 \text { ) } \\
2.326 \text { (sig. } 0.047 \text { ) }\end{array}$ & 0.622 & 2.365 \\
\hline 4 & $\begin{array}{l}\text { Uninstall the formwork } \\
\text { - } \mathrm{BBKBP3} \\
\text { - } \mathrm{BBKK} 4\end{array}$ & 4.755 & $\begin{array}{l}2.740(\mathrm{sig} .011) \\
2.257 \text { (sig .047) }\end{array}$ & 0.763 & 1.989 \\
\hline
\end{tabular}
BBKBP3 will increase the level of quality of work of uninstall formwork of 1.149. Third, the regression coefficient BBKK4 of 0.954 stated that any increase (due to the (+) sign) 1 unit of BBKK4 will increase the level of quality of work of uninstall formwork of 0.954 .

Table 1. Test Results Summary

Source: data processed

\subsection{Install the formwork}

Simultaneous influence test (test F) install the formwork using ANOVA test (Analysis of Variance) or F-statistics, obtained an F count of 28.671 there are significant effects simultaneously of the variables BKBP8 and BKK3 against the quality level of formwork.

Partial influence test ( $\mathrm{t}$ - test) formwork using regression model produced t-test of 0.039 and 0.024 for BKBP8 to BKK3, so it can be inferred that the variables BKBP8 and BKK3 effect significantly to quality of formwork. $t$-count for model regression of 2.954 to BKBP8 and BKK3 to 2.395, where $\alpha=0.05,(\mathrm{n}-1)=30-1 \mathrm{t}=29)$ table of 
2.045. It can be concluded that the deciding free variables (BKBP8 and BKK3) effect significantly to the quality level of formwork.

$\mathrm{R}$ Square install the formwork 0.680 explains that the contribution of a given variable work install formwork against quality level of $68.00 \%$ while the rest of $32.00 \%$ are influenced by factors others are not examined.

The Durbin-Watson values count are on the interval between $\mathrm{du}<4-\mathrm{DW}<\mathrm{du}$, or 1.567 $<1.947<2.433$. According the above decision-making basis, then Ho accepted or there is no correlation, so the regression model to predict the quality level of formwork.

\subsection{Ironing}

Simultaneous influence test (test F) install the formwork using ANOVA test (Analysis of Variance) or F-statistics, obtained an F count of 17,142 there are significant effects simultaneously of the variables BSBP3 and BSK7 against the quality level of ironing.

The $\mathrm{t}$-count 2.508 to BSBP3 and BSK7 to 2.275, where $\alpha=0.05,(\mathrm{n}-1)=30-1, \mathrm{t}=29)$ table of 2.257. In accordance with the provisions of if t calculate $>$ t-table $\alpha(n-1)$ then the Ho is rejected and the $\mathrm{Ha}$, so that it can be concluded that the deciding free variables (BSBP3 and BSK7) effect significantly to the quality level of ironing.

$\mathrm{R}$ square obtained 0.559 this explains that the given variable contributions ironing against the quality level of $55.90 \%$ while the rest amounted to $44.10 \%$ were influenced by other factors not examined.

The Durbin-Watson values count are on the interval between du $<4$-DW $<$ du, or 1.567 $<1,728<2.433$. According the above decision-making basis, then Ho accepted or there is no correlation, so the regression model to predict the quality level of ironing.

\subsection{Concreting}

From table obtained F count of 5.181 while the price $F$ table of 4.20 for $\alpha=0.05$, (k-1) $=(2-1)=1,(n-k)=(30-2)=28$. In accordance with the provisions of $F$ if $F>$ count table then Ho is rejected and the Ha, so that it can be concluded that there are significant effects simultaneously (simultaneous) of the variables CRBP7 and CRK2 against the quality level and model concreting work

The obtained t-count of 2.332 to CRBP7 and to CRK2 2.326, where $\alpha=0.05$, (n-1) $=$ $30-1 \mathrm{t}=29)$ table of 2.045. In accordance with the provisions of if $t$ calculate $>t$ table $\alpha(n-1)$ then Ho denied and Ha is received. It can be concluded that the variables CRBP7 and CRK2 effect significantly to quality level job concreting.

$\mathrm{R}$-square value 0.622 shows that the contribution of a given variable concreting work against quality level of $62.20 \%$ while the rest of $37.80 \%$ were influenced by other factors not examined.

The value of the Durbin-Watson count are on the interval between $\mathrm{du}<4$-DW $<\mathrm{du}$, or $1.567<2.365<2.433$. According the above decision-making basis, then Ho accepted or there is no correlation. So the regression model to predict the quality level worthy job concreting.

\subsection{Uninstall the Formwork}

From table obtained F count amounted to 4.755 while the price $\mathrm{F}$ table of 4.20 for $\alpha=$ $0.05,(\mathrm{k}-1)=(2-1)=1,(\mathrm{n}-\mathrm{k})=(30-2)=28$. In accordance with the provisions of $\mathrm{F}$ if $\mathrm{F}>$ count table then Ho is rejected and the Ha, so that it can be concluded that there are significant effects simultaneously of the variables BBKBP3 and BBKK4 against the quality level of install the formwork.

The obtained t-count of 2.740 for BBKBP3 and for 2.257 BBKK4, where $\alpha=0.05$, (n$1)=30-1 \mathrm{t}=29)$ table of 2.045. It can be concluded that the variables BBKBP3 and BBKK4 effect significantly to the quality level of install the formwork.

$\mathrm{R}$-square value 0.763 shows that the contribution of uninstall the formwork against 
quality level of $76.30 \%$ while the rest of $23.70 \%$ were influenced by other factors.

The value of the Durbin-Watson count are on the interval between du $<4$-DW $<\mathrm{du}$, or $1.567<1989<2.433$. According the above decision-making basis, then Ho accepted or there is no correlation. So the regression model to predict the quality level worthy of a job uninstall the formwork.

\section{Conclusion}

The performance of the project implementation until the 27 th week of aspects of project implementation costs, not experiencing excess costs, but the implementation of the projects experienced delays. The implementation of the project to date is still running, if the performance of the execution of the project remains the same until the project is completed, then the cost for concrete will be needed amounting to $\mathrm{Rp} 72,723,869,102$ with a value of Variance at Completion (VAC) Rp 13,736,780,898, the cost of implementation is less than budget plan amounted to Rp 86,460,650,000. The aspect of time, when the performance doesn't update then it will happen, for concrete project delay completion of the project for 83 weeks which means the projects experienced delays for 28 weeks of the time specified in the contract that is over 55 week.

The work of formwork Y_BK $=4,052+1,757$ BKBP8 $+0,476$ BKK3. There are 2 (two) dominant variables influencing the quality of formwork BKBP8 (in concrete level marking) and BKK3 (dimensions in the formwork).

The work of ironing Y_BS $=-0,499+(-0,214)$ BSBP3 $+(-0,300)$ BSK7. There are 2

(two) dominant variables influencing the quality of ironing BSBP3 (Connection/overlay/cuttings iron reinforcement) and BSK7 (iron is clean, free from rust, oil, and the concrete is dry).

The work of concreting Y_CR $=8,387+0,337$ CRBP7 + 1,871 CRK2. There are 2 (two) dominant variables affect the quality of the concreting CRBP7 (checking of slump test) and BKK3 CRK2 (the amount of manpower the concreting).

The work of uninstall the formwork. Y_BKK $=0,893+1,149$ BBKBP3 $+0,954$ BBKK4. There are 2 (two) dominant variables influencing the quality of install formwork i.e. BBKBP3 (age of concrete) and BBKK4 (level concrete according to plan).

\section{References}

Ashokkumar D. 2014. Study of Quality Management in Construction Industry. International Journal of Innovative Research in Science, Engineering and Technology. 3(1): 2319-8753.

Aulady M, Cesaltino O. Perbandingan Durasi Waktu Proyek Konstruksi Antara Metode Critical Path Method (CPM) dengan Metode Critical Chain Project Management (Studi Kasus: Proyek Pembangunan Apartamen Menara Rungkut. Jurnal IPTEK. 20(1): 14117010.

Daulasi A, Jantje B, Mangare, Walangitan DRO. 2016. Perbandingan Biaya Proyek Gedung Empat Lantai STKIP Kie Raha Ternate eengan Metode Earned Value. Jurnal Sipil Statik. 4(2): 75-82.

Dimyati A, Hamdan, Nurjaman K. 2016. Manajemen Proyek. Bandung: Pustaka Setia.

Efendi A, Sumarsiddin LO. 2015. Pengendalian Waktu dan Biaya pada Proyek dengan Metode Earned Value (Studi Kasus Pembangunan Dermaga Kasipute Kab.Bombana). Jurnal Teknik ITS. 4(1): 2337-3539.

Hadiono B. 2010. Manajemen Pengendalian Mutu Pekerjaan Struktur Atas (Studi Kasus Proyek 1 @ Cik Ditiro Menteng Residence Jakarta.[Skripsi]. Jakarta: Jurusan Sipil. Fakultas Teknik Sipil dan Perencanaan Universitas Mercu Buana.

Maulana A. 2019. Influence of Service Quality To Customer Satisfaction PT. Pos Indonesia Karawang Branch. Journal of Management and Business. 18(1): 18-24. 
Pinontoan DM, Mitchel, Mandagi RJM, Mangare J. 2015. Pengendalian Biaya dan Waktu Dengan Metode Analisis Nilai dan Hasil dengan Microsoft Project 2010 (Studi Kasus : Gedung Mantos Tahap III). Jurnal Sipil Statik. 3(12): 787-803.

Rantung HPA, Sompie FB, Mandagi RJM. 2014. Analisis Pengendalian Biaya dan Jadwal pada Tahap Pelaksanaan Konstruksi dengan Analisis Nilai Hasil (Earned Value Analysis) Studi Kasus pada Proyek Bangunan Pengaman Pantai di Provinsi Sulawesi Utara. Jurnal Ilmiah Media Engineering. 4(3): 2087-9334.

Rivelino. 2016. Kajian Pengendalian Mutu Konstruksi pada Pengawasan Pelaksanaan Pembangunan Jaringan Irigasi Studi Kasus: Pembangunan Jaringan Irigasi di. Leuwigoong. Jurnal Konstruksia. 8(1).

Rustendi I. 2012. Aplikasi Statistical Process Control (SPC) dalam Pengendalian Variabilitas Kuat Tekan Beton. Teodolita. 14(1): 16-36.

Santosa MAW. 2013. Penerapan Standar Sistem Manajemen Mutu (ISO) 9001:2008 pada Kontraktor PT. Tunas Jaya Sanur. Jurnal Ilmiah Elektronik Infrastruktur Teknik Sipil. 2(1).

Simanjuntak RAM, Firmansyah I. 2014. Rekomendasi Hasil Analisis Waktu Pelaksanaan Konstruksi Bangunan Gedung Pemerintah Di Lingkungan Kota Serang Provinsi Banten. Jurnal Ilmiah Media Engineering. 4(4): 219-228. 